\title{
Comparative Geochemical Assessment of Heavy Metal Pollutants among the Mediterranean Deltaic Lakes Sediments (Edku, Burullus and Manzala), Egypt
}

\author{
B. N. Shalaby*, Y. M. Samy, A. O., Mashaly, and M. A. El Hefnawi \\ Geology Department, National Research Centre, El Bohooth Street, Dokki, Cairo, \\ 12622, Egypt.
}

$\mathbf{T}$ HE NORTHERN coastal-deltaic lakes (Edku, Burullus and Manzala) suffer from serious environmental pollution as they receive agricultural drainage, industrial wastewater as well as domestic wastewaters directly without any treatments. Investigation of heavy metals pollutants in coastal lake sediments shows a wide view about the state of pollution not only in the sediments but also in the water of the lakes. It also helps to carry out environmental assessment studies of these lakes in order to make a better management to control the pollution levels. The variation of concentrations in selected heavy metals $(\mathrm{Mn}, \mathrm{Zn}, \mathrm{Cu}, \mathrm{Pb}, \mathrm{Cd})$ and $(\mathrm{Fe})$ against time has been discussed and compared with average values of selected heavy metals in the present work. Certain contamination indices such as the geoaccumulation index (Igeo), the degree of contamination (DC) and the contamination factor (CF) are used to evaluate the environmental impacts of these lakes. The differences in pollution state among these major deltaic lakes are illustrated and their causes are discussed.

Keywords: Geochemical assessment, Heavy metal pollutants, Lake Sediments, Deltaic lakes, Coastal lakes.

\section{Introduction}

The Mediterranean shoreline of Egypt comprises three major deltaic fresh to brackish shallow lakes, their depth ranged from 50 to 180 $\mathrm{cm}$. These lakes from west to east are; Edku, Burullus, and Manzala. These coastal deltaic lakes occupy large part of the delta coast, reached about 115, 420 and $700 \mathrm{~km} 2$, respectively (Fig. 1). They are separated from the Mediterranean by low lying long narrow coastal sand barriers and dunes, most of these sand dunes are thought to be removed as a result of industrial, agricultural and urbanization activities [1], and connected to the sea by protected inlets. These dunes and sand barriers are composed mainly of opaques, as well as augite, hornblende, zircon, epidote, garnet, tourmaline, monazite and rutile [2]. They receive the majority of their fresh water input from irrigation drains that are connected to the lakes from the southern, eastern and western margins. The eastern and southern margins of the deltaic lakes are bordered by aquatic macrophytic plants, while the surface sediments of the lakes are composed of plant and shell fragments associated with mud, silt and sandy silt [3].

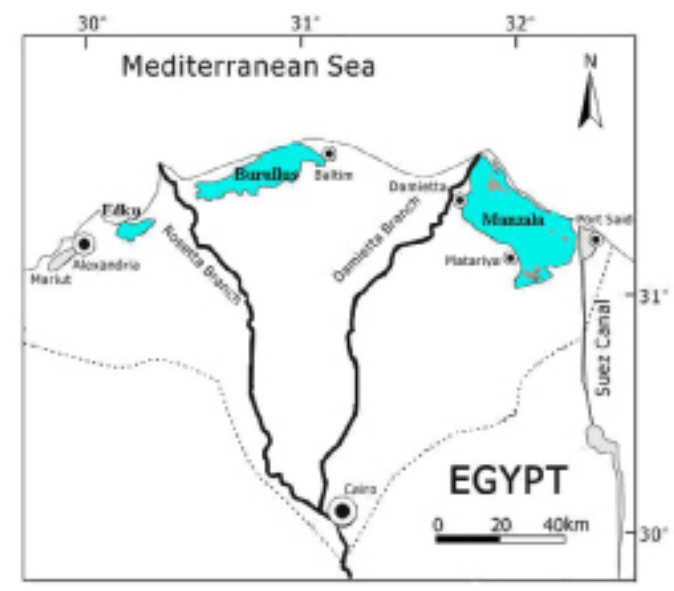

Fig.1. Mediterranean Deltaic lakes.

*Correspnding author e-mail: baselshalaby@hotmail.com baselshalaby@gmail.com 
Lake Edku is one of the northern coastal lakes in Egypt, located about $30 \mathrm{Km}$ east of Alexandria between Long. $30^{\circ} 8^{\prime} 30^{\prime \prime}$ and $30^{\circ} 23^{\prime} 0.0^{\prime \prime} \mathrm{E}$ and Lat. $31^{\circ} 10^{\prime} 30^{\prime \prime}$ and $31^{\circ} \mathrm{N}$, and covering an area of about $115 \mathrm{Km}^{2}$ ( Fig. 2). Water depth is shallow $(0.5-1.5 \mathrm{~m})$. Average salinity is 8.17 per thousand [4]. Large parts of the lake were reduced as a result of land reclamation at the eastern southern margin [5].

Lake Burullus is the second largest coastal deltaic lake in the northern Nile Delta of Egypt and covers an area of about $420 \mathrm{Km}^{2}$. It is a UNES protected area [6]. It is located in the central part of the northern coast of the Nile Delta between longitudes $30^{\circ} 30^{\prime}-31^{\circ} 10^{\prime} \mathrm{E}$ and latitudes $31^{\circ}$ $35^{\prime}-31^{\circ} 21^{\prime} \mathrm{N}$ (Fig. 3). It has a maximum depth of $175 \mathrm{~cm}$ in the middle and western parts. Salinity reaches up to $3.51 \%$. The lake receives fresh

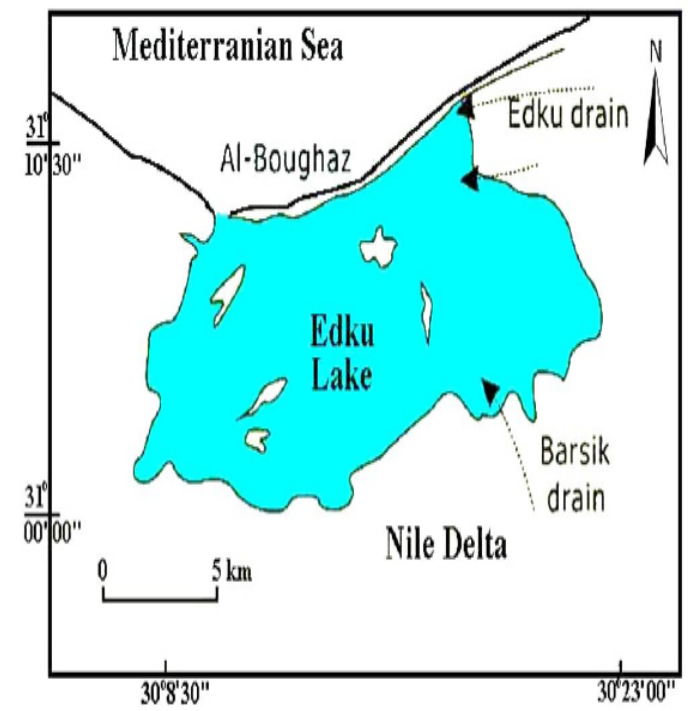

Fig. 2. Edku Lake.

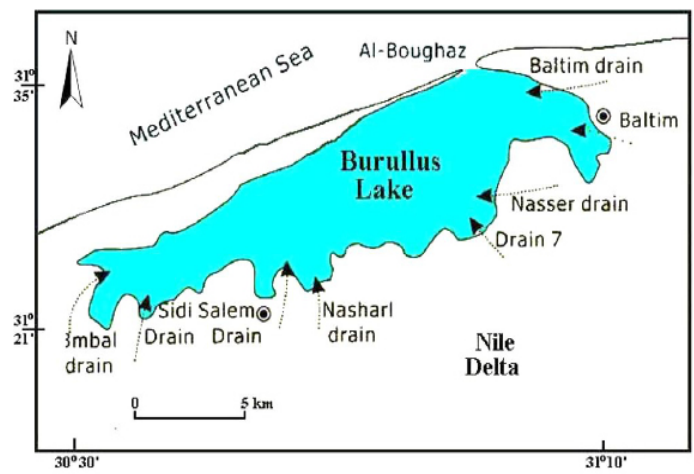

Fig. 3. Burullus Lake. water, agricultural waste and run-off water which are completely free from industrial water from several along the southern and eastern margins, [7].

Lake Manzala is the largest brackish coastal lake (about $700 \mathrm{~km}^{2}$ ), located in the northeastern shoreline of the Nile delta between Long. $31^{\circ}$ $45^{\prime}$ and $32^{\circ} 15^{\prime} \mathrm{E}$ and. Lat $31^{\circ} 00^{\prime}$ and $31^{\circ} 25^{\prime} \mathrm{N}$ (Fig. 4). The lake is shallow with an average depth of about $1.0 \mathrm{~m}$; it is connected to the Mediterranean Sea via three outlets, facilitating the exchange of the biota and water from the lake to the sea, these outlets are El Boughdady, El Gamil, and the new El Gamil [8,9]. Lake Manzala supplied about $50 \%$ of the total Egyptian fish catch in the seventies [10]. However, in the time being it supplies not more than $20 \%$ [11].

The ecosystem of these lakes is controlled by both natural and man-induced factors. In the last decade, as a result of increased population and after the construction of the Aswan High Dam, which facilitates providing cheap electric power, the industrial as well as the agricultural activities have increased rapidly in the delta region. Such obvious economic development caused serious environmental hazards, especially in the northern deltaic lakes (Edku, Burullus and Manzala). These lakes, now, are converted into huge basins in which agricultural drainage, industrial wastewater as well as sewage effluents are poured directly without any treatments [12].

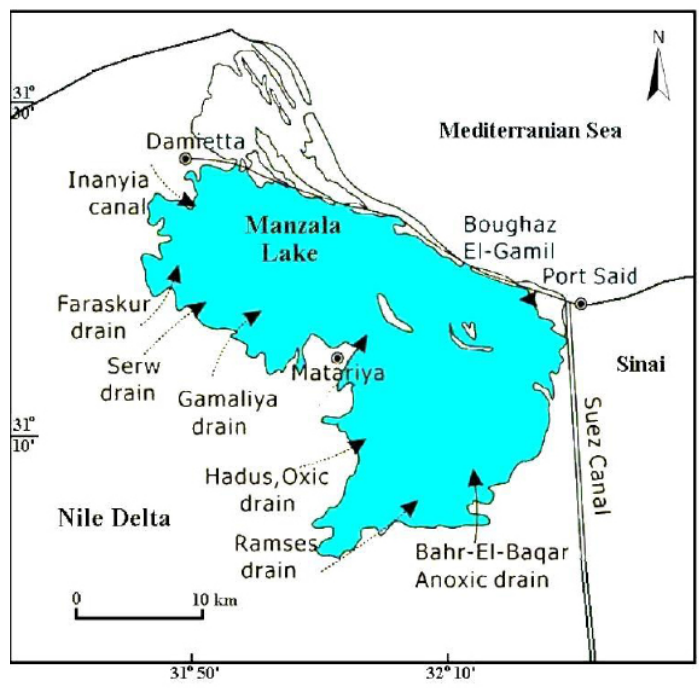

Fig. 4. Manzala Lake.

Egypt. J. Chem. 60, No. 3 (2017) 
The high concentrations of nitrogen and phosphorus in the organic waste, as well as heavy metals in water and sediments altered the ecosystem of these lakes. Consequently, these lakes suffered from environmental degradation accompanied by serious different health problems [13].

The heavy metals in the deltaic coastal lakes attracted the attention of many researchers [2, 5,6 ,8-10, 12,14], however, till now researches concerning heavy metals pollutants and their harmful effects on these three major delta lakes are still not enough especially with the present day increased environmental hazards.

A better management to control the pollution levels and to save the biota in these lakes is very important, as economically, Lake Manzala, only, providing about $20 \%$ of the annual Egyptian fish yield [11].

Aim of the work

The present article aims to:

1- Discuss the variation of concentrations in some heavy metals (Fe, $\mathrm{Mn}, \mathrm{Zn}, \mathrm{Cu}, \mathrm{Pb}$ and $\mathrm{Cd}$ ) in lake sediments with time in the major deltaic lakes (Edku, Burullus and Manzala) as well as to compare the average values of these polluting heavy metals among these lakes.

2- Evaluate the environmental impact of these lakes using certain contamination indices such as the geoaccumulation index (Igeo), the contamination factor (CF) and the degree of contamination (DC) and comparing them with reference values.

3 - Illustrate the causes and differences in pollution state among these major deltaic lakes.

\section{Experiments}

The present work is based on data obtained by the present investigation, in addition to previous published data for comparison.

Sediment samples were collected using core sampler according to the method described by Boyd and Tucker [15], during spring and autumn seasons 2015 from 9 sampling sites in Lake Edku, 12 sampling sites from Lake Burullus and 14 sampling sites from Lake Manzala, respectively (Fig. 5). Each sampling site comprises a group of samples. The samples at each site were mixed to obtain composite sample. For chemical analysis, the samples were air dried and the size fraction $<63$ microns was recovered by sieving. This size fraction was recommended to obtain homogeneous grain distribution [16], and is considered as the most chemically active sediment phase [17]. Analysis of the heavy metals was

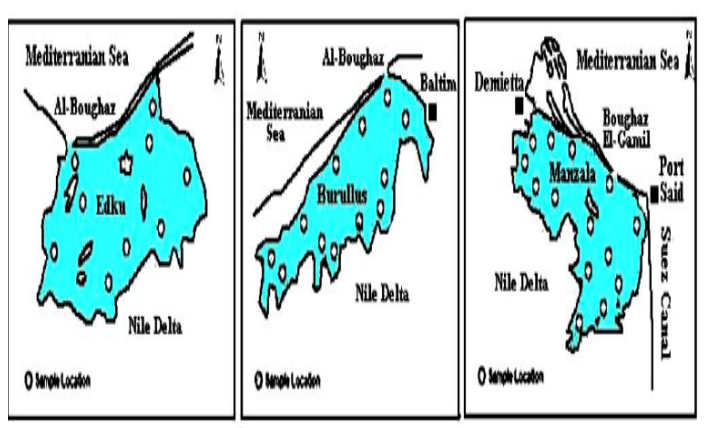

Fig. 5. Sampling site locations.

carried out according to the method described by Page et al. [18], using Flame Atomic Absorption Spectrometry (Flame-AAS, PinAAcle 900H).

The average concentration of each heavy metal at different sites is calculated and represented by one value.

\section{Results and Discussion}

Variation patterns of heavy metals pollutants by time in the northern deltaic lakes compared with the present study

All analysis were done using Flame Atomic Absorption Spectrometry:

\section{Lake Edku:}

Table 1 shows the average concentration of the studied heavy metals in Lake Edku sediments for the present study and those from previous work, the data are presented in Fig. 6.

Iron concentration showed an irregular pattern of distribution by time, (Fig.6), it fluctuates from 6.25 to $37.5 \mathrm{mg} / \mathrm{g}$. The concentrations of $\mathrm{Zn}, \mathrm{Cu}$, $\mathrm{Mn}$, and $\mathrm{Pb}$ were varied widely as they ranged from 40 to $352 \mu \mathrm{g} / \mathrm{g}(\mathrm{Zn})$, from 18 to $60 \mu \mathrm{g} / \mathrm{g}$, $(\mathrm{Cu}), 115$ to $1749 \mu \mathrm{g} / \mathrm{g}(\mathrm{Mn})$, and 4 to $37.14 \mu \mathrm{g} / \mathrm{g}$ $(\mathrm{Pb})$, Table 1 . Generally the concentrations of $\mathrm{Zn}$, $\mathrm{Cu}, \mathrm{Mn}$ and $\mathrm{Pb}$ tend to be increased by time as they attained their maximum values recently from 2008 to 2015, (Fig. 6). Cadmium, on the other hand, expressed a marked drop in its value by time as it ranged from 7.3 to $1.47 \mu \mathrm{g} / \mathrm{g}$, (Fig. 6). 
TABLE 1: The average concentration of heavy metal pollutants in Lake Edku sediments.

\begin{tabular}{|c|c|c|c|c|c|c|}
\hline $\begin{array}{c}\text { Conc.* } \\
(\mu \mathrm{g} / \mathrm{g})\end{array}$ & $\begin{array}{c}\text { El Ghobary [19] } \\
(1977)\end{array}$ & $\begin{array}{c}\text { Moussa } \\
{[20]} \\
(1984)\end{array}$ & $\begin{array}{c}\text { Abdel Moati and } \\
\text { El Samak [14] } \\
(1997)\end{array}$ & $\begin{array}{c}\text { Saeed and } \\
\text { Shaker [5] } \\
(2008)\end{array}$ & $\begin{array}{c}\text { Gu, et al. } \\
{[21]} \\
(2013)\end{array}$ & $\begin{array}{c}\text { Present } \\
\text { study }\end{array}$ \\
\hline $\mathrm{Fe}$ & 8.5 & 35 & 23.6 & 6.25 & 37.5 & 25.46 \\
\hline $\mathrm{Zn}$ & - & 40 & 317 & 344.45 & 211 & 352 \\
\hline $\mathrm{Cu}$ & 30 & 18 & 19 & 36.77 & 60 & 41.56 \\
\hline $\mathrm{Mn}$ & 145 & - & 115 & 1390.13 & 1749 & 1200 \\
\hline $\mathrm{Cd}$ & - & - & 7.3 & 1.47 & 1.65 & 2.79 \\
\hline $\mathrm{Pb}$ & 4 & 24 & 20 & 37.14 & 16.5 & 31.7 \\
\hline
\end{tabular}

(*) Fe concentration is in $(\mathrm{mg} / \mathrm{g})$
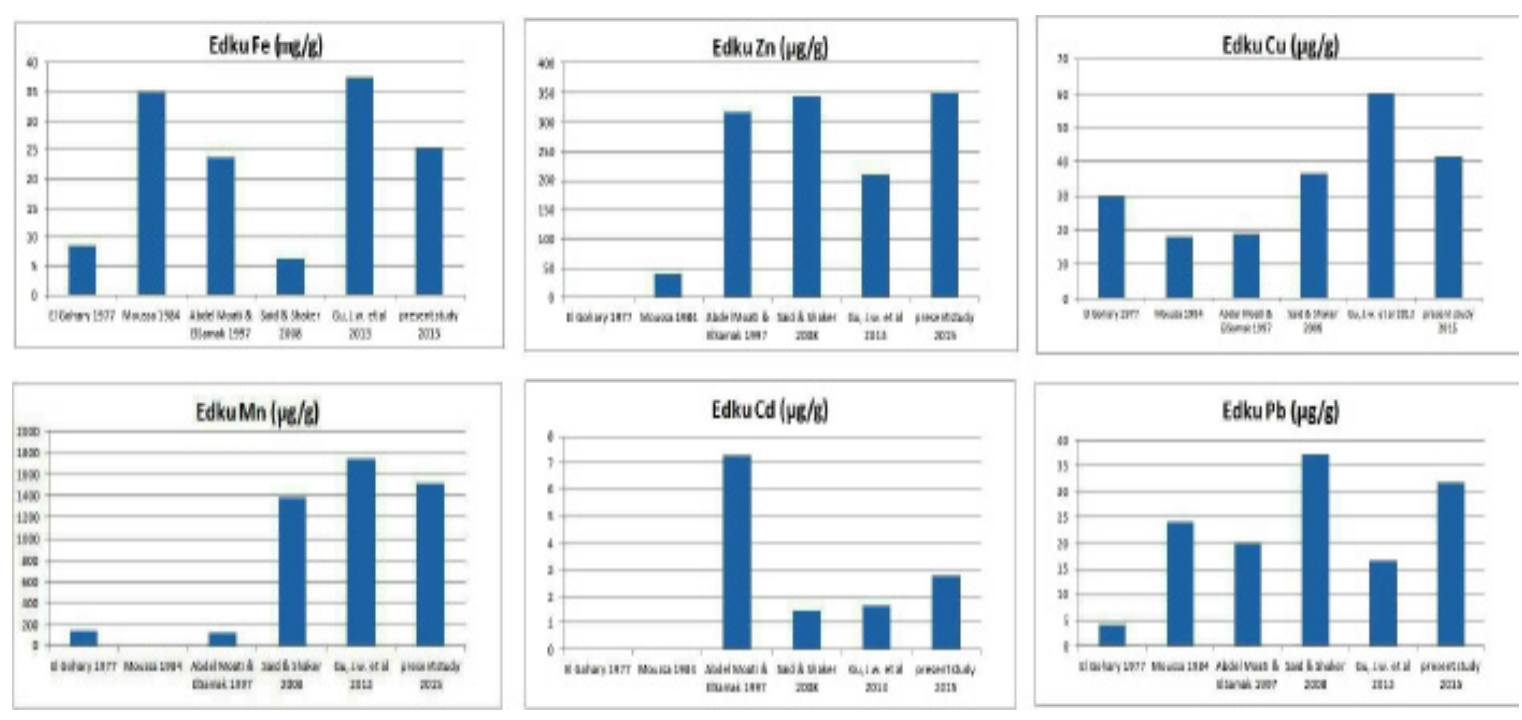

Fig. 6. Graphical presentation of the heavy metals variation by time in Lake Edku.

\section{Lake Burullus}

Table 2 and Fig.7 show the average concentrations and trends of heavy metal pollutants in Lake Burullus sediments for both the present study and other previous data.

Both of $\mathrm{Fe}$ and $\mathrm{Zn}$ concentrations showed more or less similar pattern of distribution (Fig. 7), as they fluctuated by time within a relatively wide range; they ranged from 7.94 to $61.4 \mathrm{mg} / \mathrm{g}(\mathrm{Fe})$ and 83.25 to $217.3 \mu \mathrm{g} / \mathrm{g}(\mathrm{Zn})$. Cd concentration expressed an irregular pattern of distribution by time, it is fluctuated from the lowest value of 0.086 to the highest one $8.24 \mu \mathrm{g} / \mathrm{g}$. The values of $\mathrm{Cu}, \mathrm{Mn}$, and $\mathrm{Pb}$, with few exceptions, were generally fluctuated within a narrow range with time; they varied from 25 to $59.81 \mu \mathrm{g} / \mathrm{g}(\mathrm{Cu}), 70$ to $1148.09 \mu \mathrm{g} / \mathrm{g}(\mathrm{Mn})$, and 8.20 to $17.84 \mu \mathrm{g} / \mathrm{g}(\mathrm{Pb})$.

Egypt. J. Chem. 60, No. 3 (2017)
Comparing the present data with the previous studies showed that, the highest value for $\mathrm{Cu}$, $\mathrm{Mn}, \mathrm{Cd}$ and $\mathrm{Pb}$ were recorded in the present work (Table 2).

\section{Lake Manzala}

Table 3 and Fig.8 show the heavy metal concentrations in Lake Manzala for the present study and those from previous data. Almost all values of heavy metal pollutants recorded in the sediments of Lake Manzala showed an obvious increase by time, except for iron. Heavy metals values ranged from 48.82 to $512.15 \mu \mathrm{g} / \mathrm{g}(\mathrm{Zn})$, 7.89 to $380 \mu \mathrm{g} / \mathrm{g}(\mathrm{Cu}), 419.6$ to $1550 \mu \mathrm{g} / \mathrm{g}(\mathrm{Mn})$, 0.17 to $115.48 \mu \mathrm{g} / \mathrm{g}(\mathrm{Cd})$ and $9.6 \mu \mathrm{g} / \mathrm{g}$ to 146.85 $\mu \mathrm{g} / \mathrm{g}(\mathrm{Pb})$. On the other hand, Fe showed a minor change as it fluctuated within a narrow range varied from 25.25 to $44.5 \mathrm{mg} / \mathrm{g}$ (Table 3 ). 
Comparing the data of the present work with those from the previous studies for the deltaic lakes revealed that; there is an obvious increase in $\mathrm{Zn}, \mathrm{Cu}, \mathrm{Mn}, \mathrm{Cd}$ and $\mathrm{Pb}$ concentrations in Lake Manzala by time; a marked high concentration in $\mathrm{Cu}, \mathrm{Mn}, \mathrm{Cd}$ and $\mathrm{Pb}$ in Lake Burullous was also recorded; $\mathrm{Zn}$ showed fair fluctuation in Lake Edku sediments.

Comparison of the distribution of heavy metal pollutants among the investigated northern deltaic Lakes

Table 4 and Fig.9 show the overall averages of heavy metal pollutants for the present study and those reported from previous studies in the sediments of the studied northern deltaic lakes.

The difference of heavy metals values among the three lakes is pronounced; they expressed a wide range of variation. The order of abundance of the investigated heavy metals in sediments of the three deltaic lakes were as follows, $\mathrm{Fe}>\mathrm{Mn}$ $>\mathrm{Zn}>\mathrm{Cu}>\mathrm{Pb}>\mathrm{Cd}$. The observed abundant enrichment of $\mathrm{Fe}$ and $\mathrm{Mn}$ in the investigated lake sediments may be related to the factor that $\mathrm{Fe}$ and $\mathrm{Mn}$ are among the most abundant elements of the earth's crust. All heavy metals, except Mn, showed their maximum concentration levels in

TABLE 2. The average concentration of heavy metal pollutants in Lake Burullus sediments.

\begin{tabular}{|c|c|c|c|c|c|c|c|}
\hline $\begin{array}{c}\text { Conc.* } \\
(\mu \mathrm{g} / \mathrm{g})\end{array}$ & $\begin{array}{c}\text { Abdallah } \\
\text { et al. [22] } \\
(1993)\end{array}$ & $\begin{array}{c}\text { Abdel } \\
\text { Moali and } \\
\text { El Samak } \\
{[14]} \\
(1997)\end{array}$ & $\begin{array}{c}\text { Saeed and } \\
\text { Shaker [5] } \\
(2008)\end{array}$ & $\begin{array}{c}\text { Chen, } \\
\text { et al.[6] } \\
(2010)\end{array}$ & $\begin{array}{c}\text { Gu. et al. } \\
{[21]} \\
(2013)\end{array}$ & $\begin{array}{c}\text { Samy and } \\
\text { El Bady [23] } \\
(2014)\end{array}$ & Present study \\
\hline $\mathrm{Fe}$ & 7.94 & 17.9 & 11 & 61.4 & 29.9 & 30.74 & 27.68 \\
\hline $\mathrm{Zn}$ & 101.67 & 90 & 217.33 & 96.5 & 121 & 83.25 & 94.33 \\
\hline $\mathrm{Cu}$ & 56.50 & 25 & 47.49 & 48.04 & 34 & 50.19 & 59.81 \\
\hline $\mathrm{Mn}$ & 70.00 & 85 & 850.95 & 866.5 & 933 & - & 1148.09 \\
\hline $\mathrm{Cd}$ & - & 5.2 & 4.62 & 0.086 & 1.48 & - & 8.24 \\
\hline $\mathrm{Pb}$ & 8.20 & 14 & 13.08 & 8.22 & 15 & 9 & 17.85 \\
\hline
\end{tabular}

$(*) \mathrm{Fe}$ concentration is in $(\mathrm{mg} / \mathrm{g})$.
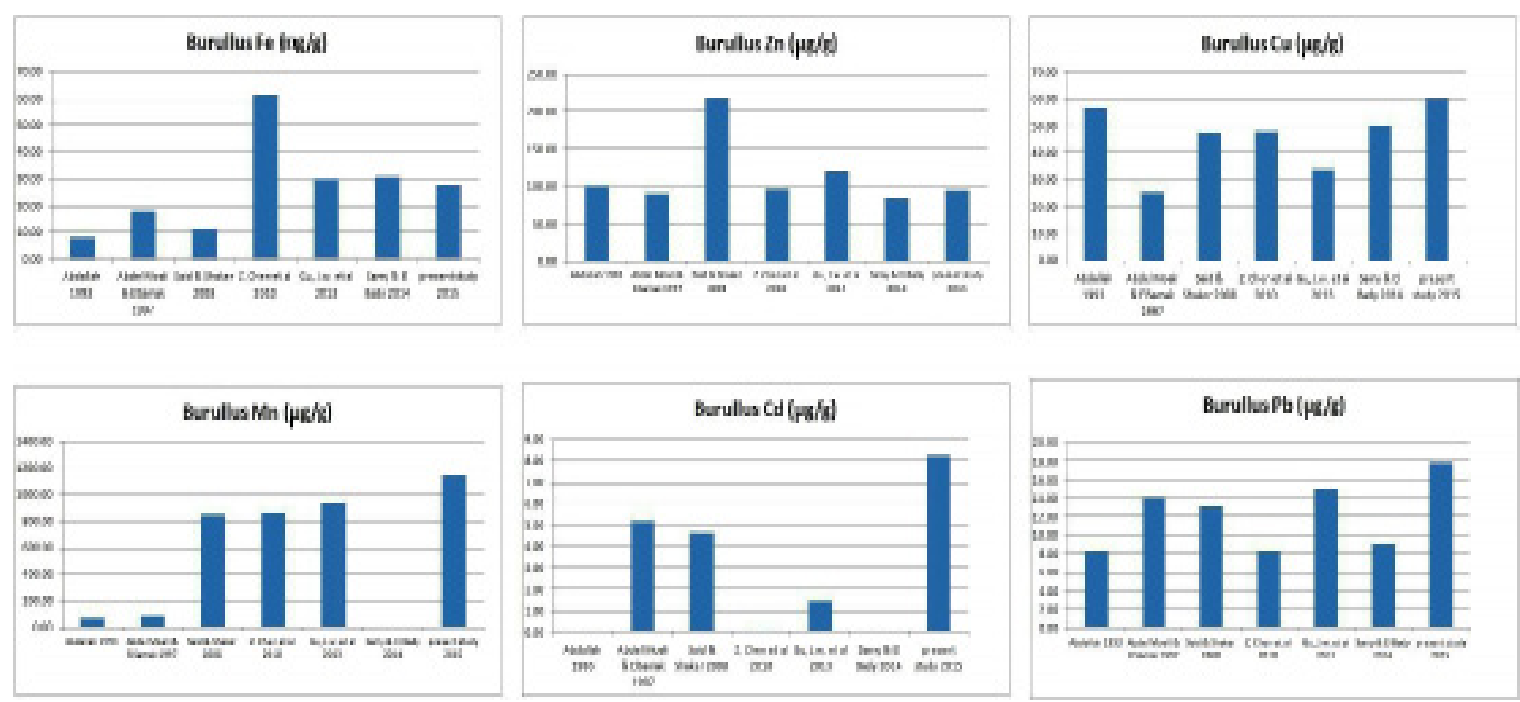

Fig. 7. Graphical presentation of the heavy metals variation by time in Lake Burullus. 
TABLE 3. The average concentration of heavy metal pollutants in Lake Manzala sediments.

\begin{tabular}{|c|c|c|c|c|c|c|c|}
\hline $\begin{array}{c}\text { Conc.* } \\
(\mu \mathrm{g} / \mathrm{g})\end{array}$ & $\begin{array}{c}\text { Saad et al. } \\
{[24]} \\
(1985)\end{array}$ & $\begin{array}{c}\text { Abdel } \\
\text { Moati and } \\
\text { Dewidar } \\
{[25]} \\
(1988)\end{array}$ & $\begin{array}{c}\text { Abdel Moati } \\
\text { and } \\
\text { El Sammak } \\
{[14]} \\
(1997)\end{array}$ & $\begin{array}{c}\text { Abdel } \\
\text { Baky et al. } \\
{[26]} \\
(1998)\end{array}$ & $\begin{array}{c}\text { Saeed and } \\
\text { Shaker } \\
{[5]} \\
(2008)\end{array}$ & $\begin{array}{c}\text { Gu, et al. } \\
{[21]} \\
(2013)\end{array}$ & $\begin{array}{c}\text { Present } \\
\text { study }\end{array}$ \\
\hline $\mathrm{Fe}$ & 44.5 & 36.5 & 35.9 & - & 33.39 & 25.2 & 37.3 \\
\hline $\mathrm{Zn}$ & 119 & 67 & 164 & 48.82 & 432.16 & 128.7 & 512.16 \\
\hline $\mathrm{Cu}$ & 207 & 42 & 74 & 7.89 & 315.36 & 35.8 & 380.45 \\
\hline $\mathrm{Mn}$ & 776 & 716 & 847 & - & 419.6 & 1045.3 & 1550 \\
\hline $\mathrm{Cd}$ & 0.17 & 7.5 & 11.8 & 1.36 & 84.8 & 1.75 & 115.48 \\
\hline $\mathrm{Pb}$ & 9.6 & 51 & 79 & 14.05 & 134.6 & 39 & 146.85 \\
\hline
\end{tabular}

(*) Fe concentration is in $(\mathrm{mg} / \mathrm{g})$
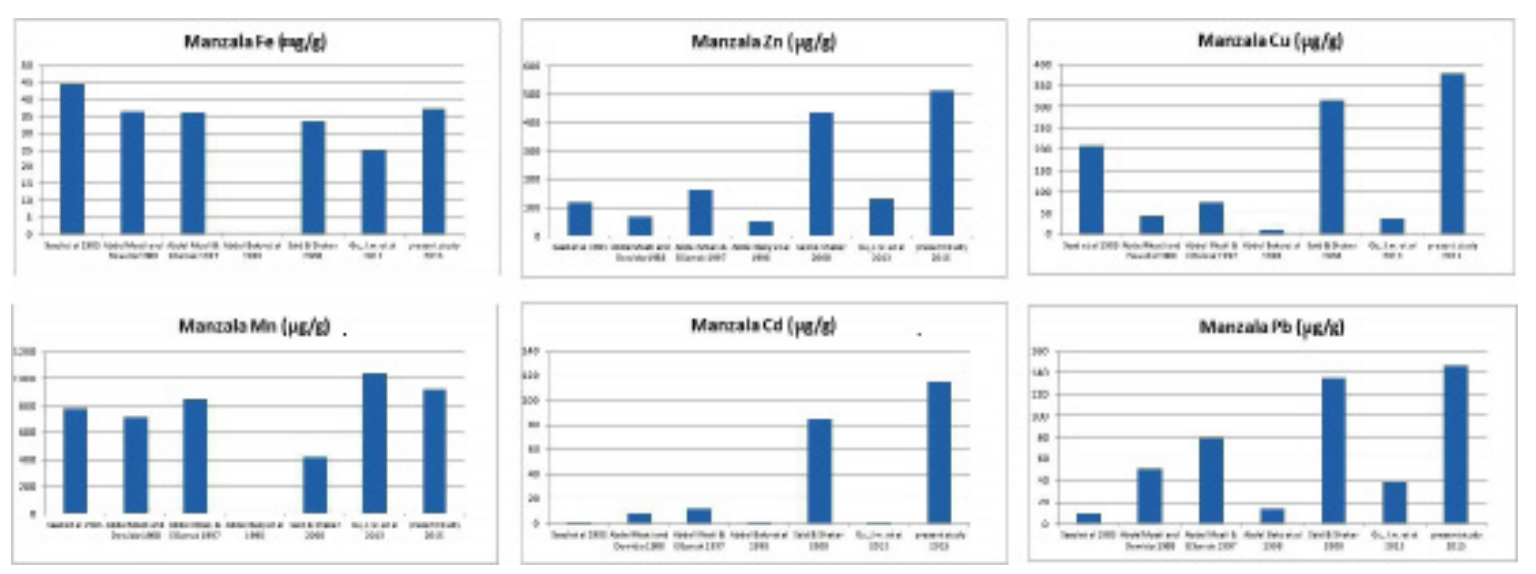

Fig. 8. Graphical presentation of the heavy metals by time of Lake Manzala.

Lake Manzala, compared to the other two lakes.

The highest concentration of $\mathrm{Fe}$ was recorded at Lake Manzala averaging; $32.9 \mathrm{mg} / \mathrm{g}$, followed by Lake Burullus $(26.7 \mathrm{mg} / \mathrm{g})$ and finally Lake Edku had the lowest concentration, averaging $22.7 \mathrm{mg} / \mathrm{g}$. The maximum value of $\mathrm{Zn}$ and $\mathrm{Mn}$ were reported from Lake Manzala, averaging, $257.2 \mu \mathrm{g} / \mathrm{g}$ and $965.48 \mu \mathrm{g} / \mathrm{g}$, respectively, Lake Edku occupies the second rank, where they averaged $252.9 \mu \mathrm{g} / \mathrm{g}$ and $919.8 \mu \mathrm{g} / \mathrm{g}$, respectively, while the minimum values were detected in Lake Burullus, averaging 114.9 and $658.9 \mu \mathrm{g} / \mathrm{g}$, respectively, (Table 4).

Cadmium had its maximum value in Lake Manzala, with an average of $43.0 \mu \mathrm{g} / \mathrm{g}$, and has nearly similar averaging values in Lakes Edku

Egypt. J. Chem. 60, No. 3 (2017) and Burullus, 3.3 and $3.93 \mu \mathrm{g} / \mathrm{g}$, respectively, (Table 4). The highest value of $\mathrm{Cu}$ was observed in Lake Manzala, averaging $162.7 \mu \mathrm{g} / \mathrm{g}$, while the lowest one recorded in lake Edku, averaging $34.2 \mu \mathrm{g} / \mathrm{g}$. Pb attained its maximum concentration in Lake Manzala, averaging $82.7 \mu \mathrm{g} / \mathrm{g}$, while the minimum value recorded in Lake Burullus, averaging $12.2 \mu \mathrm{g} / \mathrm{g}$, (Fig. 9).

Factors affecting heavy metals distribution pattern in lake sediments

The accumulation of heavy metals from overlying water to the sediments is dependent on number of external environmental factors such as, abundance of organic and inorganic legends, sediments type and the available surface area for adsorption caused by grain size distribution, $\mathrm{pH}$, $\mathrm{EC}$, ionic strength, increase of pollution rate by 
TABLE 4. Average concentration of heavy metals for the present study and those reported from previous studies in the deltaic lakes

\begin{tabular}{|c|c|c|c|}
\hline $\begin{array}{l}\text { Average* } \\
(\mu \mathrm{g} / \mathrm{g})\end{array}$ & Edku & Burullus & Manzala \\
\hline $\mathrm{Fe}$ & 22.72 & 26.65 & 32.95 \\
\hline $\mathrm{Zn}$ & 252.89 & 114.87 & 257.17 \\
\hline $\mathrm{Cu}$ & 34.22 & 45.86 & 162.7 \\
\hline $\mathrm{Mn}$ & 919.8 & 658.92 & 965.48 \\
\hline $\mathrm{Cd}$ & 3.3 & 3.93 & 43.04 \\
\hline $\mathrm{Pb}$ & 22.22 & 12.19 & 82.7 \\
\hline
\end{tabular}

(*) Fe concentration is in $(\mathrm{mg} / \mathrm{g})$

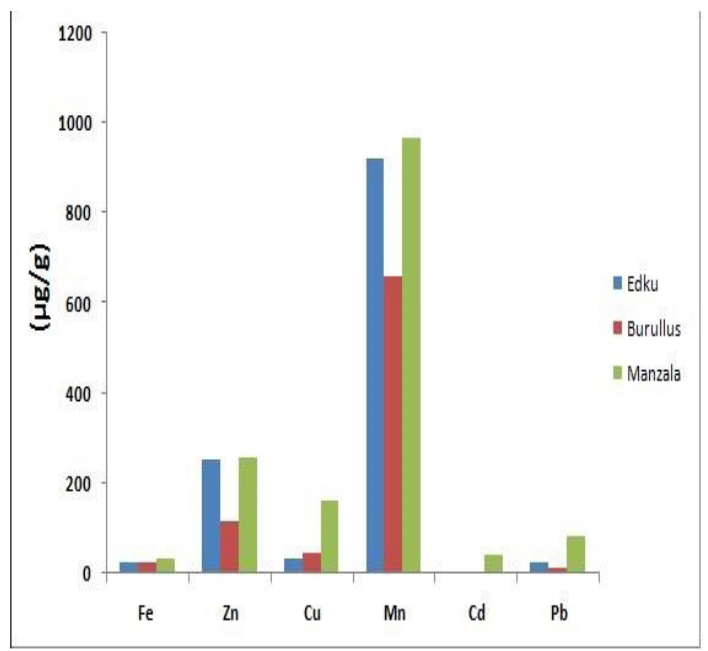

Fig. 9. Graphical presentation of the average heavy metals in the three Lakes, (Fe concentrations in $\mathbf{m g} / \mathrm{g}$ ).

time, as well as amount of anthropogenic input, in addition to the site and season at which the sample is taken [27].

\section{Sampling sites}

At sampling sites in which the lake is connected to the Mediterranean Sea, (Boughazes), the occurrence of organic matter is limited due to the action of the tidal currents which prevent their accumulation. On the other hand, sites of high fishermen activities and near fish farms are characterized by their high organic matter contents, and high $\mathrm{pH}$ values, which in turn regulate the concentration of heavy metals in sediments.

At Boughazes, where salinity and $\mathrm{pH}$ values increases, $\mathrm{Pb}$ concentrations increase by decreasing solubility, so it tends to be accumulated in sediments. On the other hand, sites in vicinity of drains show high concentration of heavy metals than in the middle parts or at Boughazes. Moreover, the sediments opposite to the drains are rather fine and rich in their organic matter contents, facilitating the absorption of abundant heavy metals [5].

\section{Seasonal variation}

The difference in abundance of some of heavy metals among different authors may be due to the difference in the season at which the samples were collected. As mentioned before, hot seasons are characterized by the enrichment of organic matter which facilitates settling of heavy metals to the sediments $[23,28]$. On the other hand, during cold seasons the obvious decreased concentrations of some heavy metals may be due to the movement of these heavy metals from sediments to the overlying water layers due to microbial activity as well as low values of $\mathrm{pH}$ [29].

The abundance of heavy metals in sediments is largely controlled by seasonal variation, iron tends to be more abundant in hot seasons due to rise in temperature, which decreases the assimilation rate of $\mathrm{Fe}$ by aquatic organisms especially macrophytes [30], so it tends to be settled in organic matter which is more abundant during hot seasons.

Mn exhibited lower values during hot seasons than cold ones, which is related to migration of $\mathrm{Mn}$ from the sediments to the water due to the decomposition of organic particles by microbial activity [31].

Zinc showed increase in hot seasons (summer and autumn) which is attributed to its uptake by macrophytes and its adsorption into the clayey particles and then sedimentation to the underlying sediments [32]. $\mathrm{Cu}$ also showed an obvious abundance during hot seasons, by increase of temperature, it tends to precipitate in sediments as $\mathrm{Cu}$ sulphide [33]. On the other hand, $\mathrm{Pb}$ and $\mathrm{Cd}$ decreased in sediments during spring and summer, the rise in temperature lead to mobilization of these elements from the sediments then their liberation to the water [30].

\section{Abundance of organic matter content}

Organic matter is considered as an important host of heavy metals on which they can be adsorbed and accumulated during weathering process $[23,34]$. Organic matter content is higher 
during hot seasons which is most probably due to flourishing of phyto and zoo plankton, that led in turn to high organic productivity $[15,28]$. On cold periods, the rate of organic matter decomposition is very high with the presence of high oxygen content.

The increase of some heavy metals than other is due to the increase in organic matter concentrations which permit settling of heavy metals into sediments [5].

\section{Sediment type and grain size}

Variation in the lake sediments largely affected heavy metals distribution. Sediments rich in their sand content and low values of organic matter are characterized by low heavy metals concentrations $[5,35]$.

It is worthy to note that, the capacity of sediments to adsorb different ions of heavy metals from the surrounding waters has a certain limit. Carbonate sandy sediments such as in Boughaz areas have the lowest capacity while sediments enriched in their clayey and organic matter contents have the highest adsorption capacity. Saeed and Shaker [5] mentioned that, lake sediments are composed mainly of clay minerals which are considered as the main host of heavy metals.

The textural characteristics of the sediments are major controlling factor that should be taken into consideration when interpreting heavy metals distribution in sediments. Generally, finer sediments show enrichment of most of heavy metals pollutants in comparison with sandy sediments. Actually clay and silt are the chemically active part of sediment and their amount in a sandsilt clay mixture strongly controls heavy metals concentrations, the latter tend to concentrate in the fine mud fractions. The higher concentration in the fine sediments is due to increase in specific surface area and to the surface properties of fine grained sediments [36].

Estimation of heavy metal pollutants risk in the northern deltaic lakes

To obtain an accurate and reliable picture about heavy metal pollutant risk in a given environment, single, as well as integrated contamination indices have been widely applied. These indices include the contamination factor $(\mathrm{CF})$, the degree of contamination (DC), geo-accumulation index

Egypt. J. Chem. 60, No. 3 (2017)
(Igeo) and ecological risk factor (Er). However, comparison with a reference values is also used as an important, valuable tool for heavy metals risk assessment.

\section{Contamination factor (CF), [37, 38]:}

The calculated contamination factor for the data of the present work is shown in Table 5 and represented in Fig. 10, the contamination factor (CF) is calculated according to the following equation:

$$
\mathrm{CF}=\mathrm{C}_{\mathrm{i} 0}-1 / \mathrm{C}_{\mathrm{in}}
$$

where: $\mathrm{C}_{\mathrm{i} 0}-1$ : metal concentration in sediment. $\mathrm{C}_{\text {in }}$ : background base value for each element (Table 9).

Figure 10 shows that, Fe has low contamination values in the sediments of the three lakes while Mn shows moderate contamination pattern in the sediments of the investigated lakes. Zn shows low contamination values in Lake Burullus but shows considerable contamination values in Lake Edku and Manzala sediments. $\mathrm{Pb}$ shows high contamination values in Lake Manzala sediments; in Lake Burullus it shows low contamination while in Lake Edku sediments it shows moderate contamination values. $\mathrm{Cu}$ shows low contamination values in Lake Edku, moderate in Lake Burullus and high contamination values in Lake Manzala sediments. Cd shows high contamination values in the sediments of the investigated three lakes.

Degree of contamination (DC) [37]:

The Degree of contamination (DC), for the data of the present work is shown in Table 5 and Fig. 11, and is calculated according to:

$$
\mathrm{DC}=\sum{ }_{1}^{\mathrm{n}} \mathrm{CF}
$$

where $\mathrm{CF}$ : is the single contamination factor

$\mathrm{n}$ : is the count of the elements present

TABLE 5. The contamination factor (CF) and the degree of contamination (DC) for the data of the present work:

\begin{tabular}{|c|r|r|r|r|r|r|r|}
\hline \multirow{2}{*}{ Lake } & \multicolumn{5}{|c|}{ CF } & \multirow{2}{*}{ DC } \\
\cline { 2 - 7 } & $\mathrm{Fe}$ & $\mathrm{Mn}$ & $\mathrm{Zn}$ & $\mathrm{Pb}$ & $\mathrm{Cu}$ & $\mathrm{Cd}$ & \\
\hline Edku & 0.54 & 1.41 & 3.7 & 1.59 & 0.92 & 9.3 & 17.4 \\
\hline Burullus & 0.59 & 1.35 & 0.99 & 0.89 & 1.33 & 27.47 & 32.62 \\
\hline Manzala & 0.79 & 1.82 & 5.4 & 7.34 & 8.45 & 384.93 & 408.73 \\
\hline
\end{tabular}




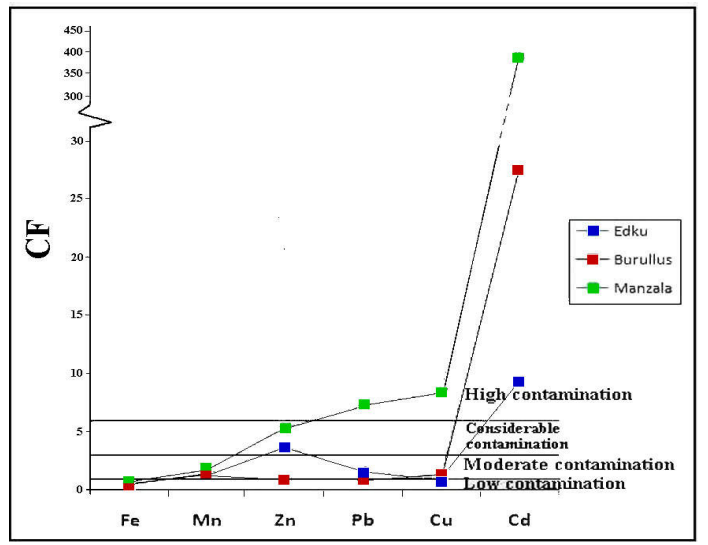

Fig. 10. Contamination factor (CF) after Hankanson [37], Tomlinson et al. [38]; classes boundaries are:

$$
\begin{aligned}
& \mathrm{CF} \leq 1 \text { : low contamination. } \\
& 1<\mathrm{CF} \leq 3 \text { : Moderate contamination. } \\
& 3<\mathrm{CF} \leq 6 \text { : Considerable contamination. } \\
& \mathrm{CF}>6 \text { : High contamination. }
\end{aligned}
$$

Lake Edku shows a moderate degree of contamination (17.4), while Lake Burullus and Manzala show a very high degree of contamination, (Fig. 11).

Geo-accumulation index (Igeo) [39, 40]:

The calculated geo-accumulation index (Igeo), for the data of the present work is shown in Table 6 and represented in Fig. 12, and is calculated from the following equation:

$$
\text { Igeo }=\log 2(\mathrm{Cn} / 1.5 \mathrm{Bn})
$$

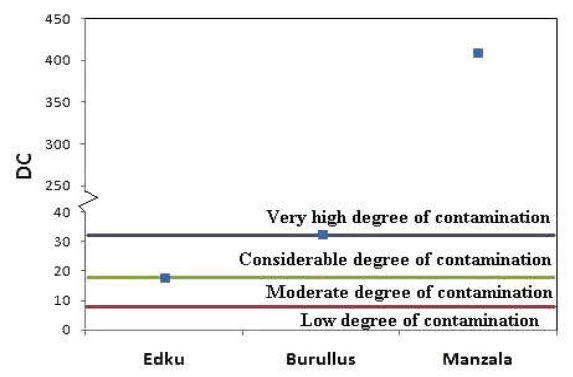

Fig. 11. Degree of contamination (DC) of the present work, class's boundaries after Hankanson [37]:

DC $\leq 8 \quad$ : Low degree of contamination.

$8<\mathrm{DC} \leq 18$ : Moderate degree of contamination. $18<\mathrm{DC} \leq 32$ : Considerable degree of contamination. DC $>32$ : Very high degree of contamination. where $\mathrm{Cn}$ : is the measured concentration of the metal $\mathrm{n}$ in the sediment

$\mathrm{Bn}$ : is the geochemical background value, (see Table 9).

As shown in Fig. 12, the sediments of lakes Edku and Burullus are unpolluted with respect to $\mathrm{Fe}, \mathrm{Mn}, \mathrm{Cu}$ and $\mathrm{Pb}$ in the sediments of the two lakes, Lake Burullus is unpolluted to moderately polluted with respect to $\mathrm{Zn}$, while $\mathrm{Zn}$ in Lake Edku sediments show moderately polluted. Lake Manzala sediments show unpolluted values for $\mathrm{Fe}$ and unpolluted to moderately polluted for $\mathrm{Mn}$, and moderately to strongly polluted for $\mathrm{Zn}, \mathrm{Cu}$ and $\mathrm{Pb}$. Cd shows moderately polluted value in

TABLE 6. Geoaccumulation index of the elements in the studied lake sediments:

\begin{tabular}{|c|c|c|c|}
\hline Element & Edku & Burullus & Manzala \\
\hline $\mathrm{Fe}$ & -1.50 & -1.40 & -0.90 \\
\hline $\mathrm{Mn}$ & -0.10 & -0.20 & 0.30 \\
\hline $\mathrm{Zn}$ & 1.90 & 0.03 & 2.40 \\
\hline $\mathrm{Cu}$ & -1.50 & -1.00 & 1.70 \\
\hline $\mathrm{Cd}$ & 1.90 & 3.50 & 7.30 \\
\hline $\mathrm{Pb}$ & -0.60 & -1.40 & 1.60 \\
\hline
\end{tabular}

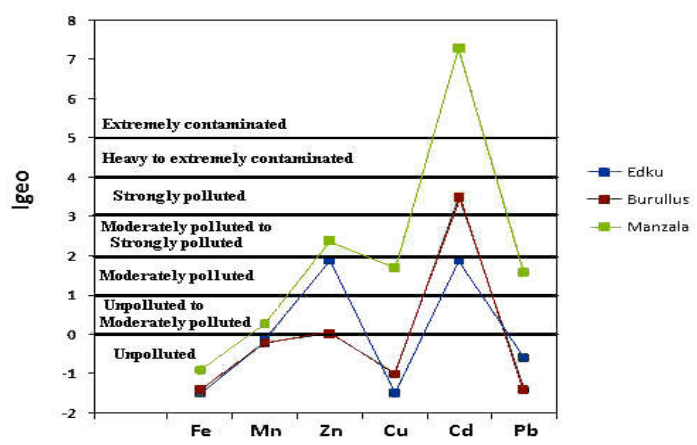

Fig. 12. Geoaccumulation index (Igeo), of the present work, classes boundaries after Muller [39], Praveena et al. [40], class's boundaries are: Igeo $<0$ : Unpolluted.

$0 \leq$ Igeo $<1$ : Unpolluted to moderately polluted.

$1 \leq$ Igeo $<2$ : Moderately polluted.

$\mathbf{2} \leq$ Igeo $<3$ : Moderately to strongly polluted.

$3 \leq$ Igeo $<4$ : Strongly polluted.

$4 \leq$ Igeo $<5$ : Heavy to extremely contaminated. Igeo $\geq 5$ : Extremely contaminated. 
Lake Edku, strongly polluted in Lake Burullus and extremely polluted in Lake Manzala.

\section{Ecological risk factor (Er) [37]}

This factor is a combination between contamination factor and the "toxic response factor" (Tr). $\mathrm{Er}=\operatorname{Tr} \times \mathrm{CF}$. The $\operatorname{Tr}$ values of $\mathrm{Pb}$, $\mathrm{Cu}, \mathrm{Cd}$ and $\mathrm{Zn}$ are 5, 5, 30 and 1, respectively [37]. The calculated Er value of the present work are shown in Table 7 and represented in Fig. 13.

Figure 13 shows that, both $\mathrm{Zn}$ and $\mathrm{Pb}$ have low potential ecological risk factor in the sediments of the investigated three deltaic lakes. $\mathrm{Cu}$ in Lake Edku and Burullus shows low potential ecological risk factor while in Lake Manzala it shows moderate potential risk factor. Cd in Lake Edku expressed high potential ecological risk factor, while in Lake Burullus and especially in Lake Manzala shows very high ecological risk factor,

TABLE 7. Ecological risk (Er) factor of the three investigated lakes sediments:

\begin{tabular}{|c|c|c|c|}
\hline Element & Edku & Burullus & Manzala \\
\hline $\mathrm{Zn}$ & 3.7 & 0.99 & 5.4 \\
\hline $\mathrm{Cu}$ & 4.6 & 6.65 & 42.25 \\
\hline $\mathrm{Cd}$ & 279 & 824.1 & 11547.9 \\
\hline $\mathrm{Pb}$ & 7.95 & 4.45 & 36.7 \\
\hline
\end{tabular}

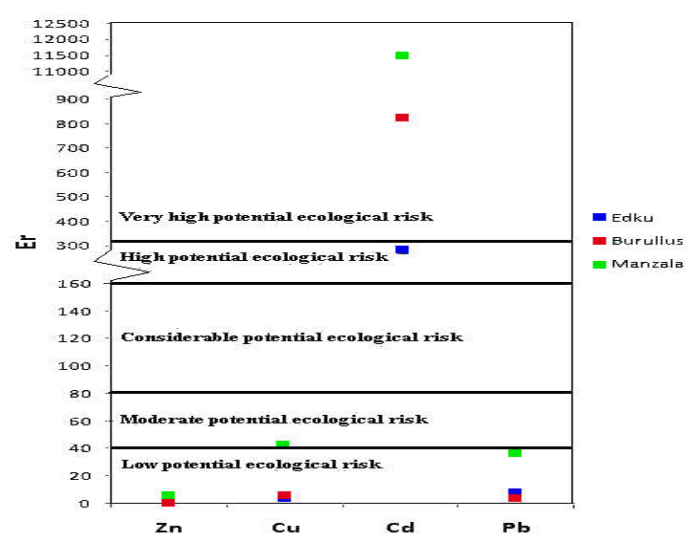

Fig. 13. Ecological risk Factor (Er), of the present work, classes boundaries after Hankanson [37]:

Er $<40$ : Low potential ecological risk.

$40<\mathrm{Er}<80$ : Moderate potential ecological risk.

$80<\mathrm{Er}>160$ :Considerable potential ecological risk.

$160<\mathrm{Er}<320$ : High potential ecological risk.

Er $>320 \quad$ : Very high potential risk. the same results were reported by EL-Bady [41].

\section{Sediments quality guidelines}

The average concentrations of $\mathrm{Zn}, \mathrm{Cu}, \mathrm{Pb}$ and $\mathrm{Cd}$ in the investigated deltaic lakes have been compared with the probable effect level (PEL) and the threshold effect level (TEL) guidelines for toxic biological effects [42], as well as sedimentquality guidelines cited by Salomons and Forstner [43]. The average concentration values of the present studied heavy metals compared with different standard guidelines are listed in Table 8 and represented in Fig. 14.

From Fig.14 it is revealed that, for Lake Edku sediments, $\mathrm{Zn}$ is much higher than both the PEL and TEL guidelines of USPHS [42], and is much higher also than the values reported by Salomons and Forstner [43]. $\mathrm{Cu}$ concentrations are higher than TEL and lower than PEL of USPHS [42], and lower than the values reported by Salomons and Forstner [43]. Pb concentration is slightly higher than TEL, but obviously lower than PEL guidelines of USPHS [42], it is fairly higher than the guidelines cited by Salomons and Forstner [43]. Cd value is higher than TEL, and lower than PEL of USPHS [42], it showed a higher concentration compared with that cited by Salomons and Forstner [43].

The investigated heavy metals in the northern deltaic lakes, compared with the probable effect level (PEL) and the threshold effect level (TEL) guidelines for toxic biological effects established by USPHS [42], and with sediment quality guidelines cited by Salomons and Forstner [43].

For Lake Burullus, $\mathrm{Zn}$ is less than the value recorded by PEL and TEL guidelines of USPHS [42]; it is also lower than the acceptable level given by Salomons and Forstner [43]. $\mathrm{Cu}$ is higher than TEL and markedly lowers than PEL of USPHS [42], while it is fairly higher than the permissible guidelines cited by Salomons and Forstner [43]. $\mathrm{Pb}$ concentration is much lower than PEL and TEL guidelines of USPHS [42], and it is also lower than that given by Salomons and Forstner [43]. Cd level is higher than the acceptable guidelines given by Salomons and Forstner [43] and USPHS [42].

For Lake Manzala the concentrations of all the examined heavy metals $(\mathrm{Zn}, \mathrm{Cu}, \mathrm{Pb}$ and $\mathrm{Cd}$ ) were obviously higher than the acceptable guidelines 
TABLE 8. Sediments quality guidelines of the investigated heavy metals in the northern deltaic lakes:

\begin{tabular}{|c|c|c|c|c|c|c|}
\hline \multirow{2}{*}{ Metals } & \multicolumn{2}{|c|}{ USPHS [42] } & $\begin{array}{c}\text { Salomons } \\
\text { and } \\
\text { Forstner } \\
{[\text { [43] }}\end{array}$ & \multicolumn{3}{|c|}{ Present study } \\
\cline { 5 - 7 } & TEL & PEL & Edku & Burullus & Manzala \\
\hline $\mathrm{Zn}$ & 124 & 271 & $<100$ & 352 & 94.33 & 512.16 \\
\hline $\mathrm{Cu}$ & 18.7 & 108 & $45-50$ & 41.56 & 59.81 & 380.45 \\
\hline $\mathrm{Pb}$ & 30.2 & 112 & $20-30$ & 31.7 & 17.85 & 146.85 \\
\hline $\mathrm{Cd}$ & 0.68 & 4.21 & 1 & 2.79 & 8.24 & 115.48 \\
\hline
\end{tabular}

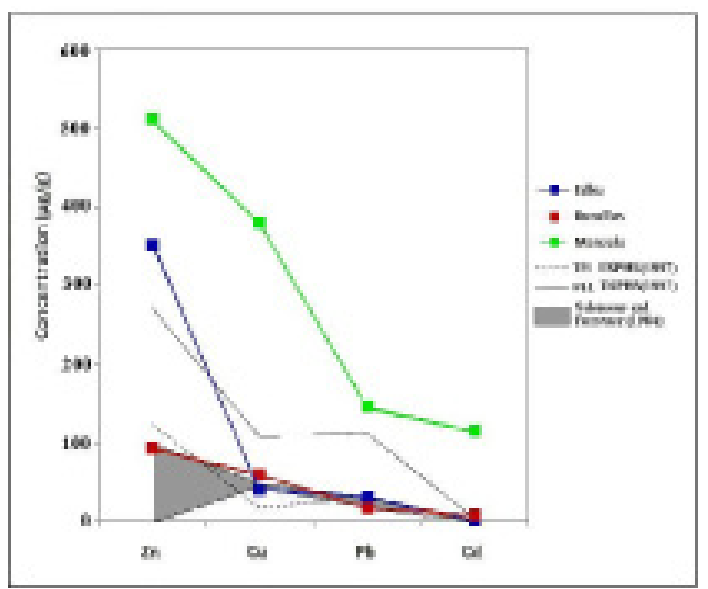

Fig. 14. Sediments quality guidelines of the investigated heavy metals in the northern deltaic lakes, compared with the probable effect level (PEL) and the threshold effect level (TEL) guidelines for toxic biological effects established by USPHS [42], and with sediment quality guidelines cited by Salomons and Forstner [43].

given by Salomons and Forstner [43], and they also markedly exceeded the permissible values cited by PEL and TEL guidelines of USPHS [42].

The obtained results are in a good agreement with those of Saeed and Shaker [5], they mentioned that, $\mathrm{Mn}$ in Lake Edku and Cd in Lake Manzala recorded higher values than the sediment quality guidelines.

In the present study, the pollution state of the studied heavy metals is classified into three levels according to the standard rules recommended for sediment pollution and modified by FreretMeurer, et al. [44]. These levels are:

1- The lowest effect level (LEL).

2- The heavily polluted category (HPC).

3- The severe effect level (SEL).

The pollution state of the present work is given in Table 9. Fe mean concentration in Lake Edku was higher than (LEL), and nearly the same as (HPC) but lower than (SEL). For Lakes Burullus and Manzala, Fe concentration was higher than LEL and HPC, but lower than SEL. Mn mean concentration in the three lakes is higher than (LEL), (HPC) and (SEL). Cd mean concentration in Lake Edku was higher than (LEL) but lower than (HPC) and (SEL), in Lake Burullus is higher than (LEL) and (HPC) but lower than (SEL). For Lake Manzala Cd shows very high concentration compared to (LEL),(HPC) and (SEL). Cu mean concentration in Lake Burullus is higher than (LEL) and (HPC), but lower than (SEL). For Lake Edku it is higher than (LEL), but lower than (HPC) and (SEL). In Lake Manzala sediments, $\mathrm{Cu}$ recorded higher values than the standard three levels.

In Lake Edku, $\mathrm{Pb}$ mean concentration was within the (LEL) category, but lower than (HPC) and (SEL) values. For lake Burullus $\mathrm{Pb}$ mean value is lower than the three standard levels, while in lake Manzala sediments $\mathrm{Pb}$ mean concentration showed higher values than (LEL) and (HPC) but

TABLE 9. Classification of pollution levels (total means) in $\mu \mathrm{g} / \mathrm{g}$ of the studied deltaic lakes, after Freret-Meurer et al. [44]:

\begin{tabular}{|c|c|c|c|c|c|c|c|}
\hline Metals & Back ground* & Edku & Burullus & Manzala & LEL $(\mu \mathrm{g} / \mathrm{g})$ & HPC $(\mu \mathrm{g} / \mathrm{g})$ & $\begin{array}{l}\text { SEL } \\
(\mu \mathrm{g} / \mathrm{g})\end{array}$ \\
\hline $\mathrm{Fe}$ & 47200 & 25460 & 27680 & 37300 & 20000 & 25000 & 40000 \\
\hline $\mathrm{Mn}$ & 850 & 1200 & 1148 & 1550 & 460 & 500 & 1100 \\
\hline $\mathrm{Cd}$ & 0.3 & 2.79 & 8.24 & 115.48 & 0.6 & 6 & 10 \\
\hline $\mathrm{Zn}$ & 95 & 352 & 94.33 & 512.16 & - & - & - \\
\hline $\mathrm{Cu}$ & 45 & 41.56 & 59.81 & 380.45 & 16 & 50 & 110 \\
\hline $\mathrm{Pb}$ & 20 & 31.7 & 17.85 & 146.85 & 31. & 60 & \\
\hline
\end{tabular}


lower than (SEL).

\section{Geoenvironmental hazards of the Northern Deltaic Lakes}

Coastal lakes regions generally suffer from contentious and fast variations resulted from the interaction of two main agents, the natural agents as well as the anthropogenic activities.

\section{Natural agents}

Siltation problems of lake inlets takes place as a result of the combination of sand transport in the long shore as well as cross- shore directions characteristic of most of the coastal lakes [46]. Siltation problem may cause shortening or even closing of the lake inlets resulting in navigation hazards as well as decreasing water flow in and out in the inlet channel. Keeping the inlet open is important for the fishery to keep the level of salinity down. The sand barriers of the investigated lakes are mostly subjected to sever beach erosion. Such erosion is due to the effect of the dynamic processes of waves and currents, in addition to the reduction of sediment supply as a result of the construction of the Aswan High Dam in 1964.

On the other hand, low lying deltaic areas are highly affected by any changes in sea level, especially because most deltas are actively subsiding. The global warming may be also an important cause accelerating sea- level rise, which may have an obvious effect on low- lying deltas all over the world. The Egyptian Nile delta coast is expected to be severely affected by sea- level rise [47]. Sea level rise may induce serious effects on lakes ecosystem by eroding the lake barriers that protect the lakes from the sea and in turn alter the quality of the water. Moreover, the arid climate causes insufficient water to enter the lakes to dilute the high level of polluting metals.

\section{Anthropogenic activities}

Anthropogenic activities comprise different items, land reclamation; pollution resulted from agricultural and industrial projects as well as land irrigation and domestic activities [48].

Reclamation:Large areas of the deltaic lakes have been dried up due to land reclamation. Reclamation activities are performed to create new land for cultivation and for building illegal houses. Such activities have increased the pollution of most of the deltaic lakes. Previously published data as well as satellite data revealed that some of the deltaic lakes have been dramatically reclaimed being at present less than $50 \%$ of their former size. For example, Lake Manzala has been reclaimed rapidly at an average rate of $14.1 \mathrm{Km} 2 /$ year [49]. Meanwhile, Lake Edku and Lake Burullus are being reclaimed at a lower rates being $3.6 \mathrm{Km}^{2}$ and $4.1 \mathrm{Km}^{2} /$ year, respectively [50].

In the last few decades, construction of roads, canals, as well as the uncontrolled filling activity of land reclamation has subdivided the lakes (Manzala, Burullus). Fragmentation of the lakes will accelerate the conversion of natural wetlands to anthropogenic use [51]. Reclamation projects in the southern and eastern margins have substantially decreased the size of the lakes [7].

\section{Pollution}

Recently, the coastal deltaic lakes have been subjected to pronounced ecological degradation. Huge amounts of sewage and industrial wastes, in addition to pesticides, insecticides and fertilizers that used for agricultural fields around the deltaic lakes are poured directly without any treatment in the drain system which discharges in turn into the deltaic lakes. Such heavy discharges of pollutant greatly altered the ecosystem of the lakes [52].

Pollution risk in Lake Edku: The possible sources of pollution in Lake Edku are mainly focused on agricultural and sewage from adjacent villages and towns and the industrial activities. Lake Edku receives huge amounts of terrigenous as well as anthropogenic nutrients discharge, sewage and agricultural runoff drainage water from four main drains, namely, Edku, Bousaly, El-Khairy and Berseek, situated at its eastern margins and open into the eastern basin of the lake [53].

Although, the industrial activities in vicinity to Lake Edku are rather limited, recent investigations showed that the sediment of the lake recorded high values of pollution, especially by $\mathrm{Mn}$ and $\mathrm{Pb}$. This may be attributed to that the lake is affected now by the saline water coming from neighboring Abu-Qir bay, to the west, on the other hand, the northwest wind carries large quantities of raw industrial wastes from east basin of Alexandria city [54]. The present investigation showed that except for $\mathrm{Zn}$ and $\mathrm{Mn}$ with their markedly high values, the concentration of most heavy metal pollutants were more or less fluctuated within the permissible values recorded by the sediment

Egypt. J. Chem. 60, No. 3 (2017) 
quality guide lines.

Pollution risk in Lake Burullus:Most of the previous works have agreed that, Lake Burullus is generally characterized by low heavy metal pollution compared with the other lakes on the Nile delta coast $[6,55]$. The agricultural wastes are considered as the main source of pollution in the lake, however, it must be taken into consideration that, large cities such as Tanta, Kafr -El Sheikh and El- Mahala with their high population directly poured their untreated sewage wastes in Burullous Lake through many drains [11].

The present results comply with that reported by many authors; it revealed that, excluding $\mathrm{Cd}$, expressing a high concentration level, most heavy metals recorded values which are fairly within that cited by the sediment quality guideline.

Pollution risk in Lake Manzala: Lake Manzala receives about 7500 million cubic meters of untreated industrial, agricultural and domestic water discharged annually into the lake through several channels in the western and southern sectors [56]. However, the untreated water is reduced to about 4000 million cubic meters after construction of the High dam [26]. Lake Manzala is divided into sub-basins by natural and artificial barriers. The Ginka sub-basin located in the southeast sector of the lake is known as (black spot). This sub-basin is heavily polluted by heavy metals and nutrient discharging from Bahr El Baqar drain [48], Ginka sub-basin receives a discharge of municipal sewage, lake industrial effluent, as well as agricultural runoff [57]. Very high concentration of metal pollutants is recorded in the upper $20 \mathrm{~cm}$ of the Ginka sub-basin, from industrial sources. Siegel et al. [12] recorded high values of $\mathrm{Hg}$ (822 ppm), $\mathrm{Pb}$ (110 ppm), Zn (635 $\mathrm{ppm})$, and $\mathrm{Cu}(325 \mathrm{ppm})$ in the bottom sediments of Ginka sub-basin. Siegel et al. [58] reported that $\mathrm{Pb}, \mathrm{Zn}, \mathrm{Hg}$ and $\mathrm{Cu}$ increased obviously in Lake Manzala after Aswan High Dam construction in 1964. These pollutants considerably degraded aquatic products both in quantity and quality [6].

Unfortunately, Lake Manzala is suffering from almost all serious environmental hazards. Barakat [59] mentioned that Lake Manzala suffered from the Petroleum refining industry and the related chemical by-products. This industry is responsible for about $60 \%$ of heavy metal pollutants poured into the lake. The increase of fertilizers manufacturing industries as well as petro-refineries is considered as the main source of pollution in the area.

The southern part of the lake water is characterized by very high heavy metals levels which exceed the maximum allowed concentration reported by the World Health Organization $[9,60]$.

The present study is greatly matching with most of the recent investigations about Lake Manzala, it showed that the lake suffered from pollution with most of the investigated heavy metals as their values are highly exceeding these cited for the sediment quality guidelines especially for $\mathrm{Cd}, \mathrm{Mn}$ and $\mathrm{Pb}$.

Dangerous effects of heavy metal pollutants on ecological system

Recently, the human activities on the delta coast have greatly changed the lakes ecohydrological setting [11]. It is worthy to mention that, high values of $\mathrm{Pb}, \mathrm{Mn}, \mathrm{Cu}$ and $\mathrm{Zn}$ resulting in severe health problems through food-web chain which consequently cause societal development degradation [61].

High $\mathrm{Pb}$ and $\mathrm{Mn}$ are mainly responsible of mental, kidney and digestive problems [6, 62], while $\mathrm{Cd}$ is most probably the main cause of pancreatic cancer [13]. $\mathrm{Cu}$ may be toxic to living organisms by causing disordering of structural proteins or reduction in enzyme activity. The major source of $\mathrm{Cd}$ in the lakes are discharges of untreated effluents from different industrial projects, however natural weathering could be also an additional source of Cd. It also increased as a result of agricultural wastes of the extensive irrigated area [63]. $\mathrm{Zn}$ is very important element in human growth; the main source of $\mathrm{Zn}$ in lakes is municipal waste water effluents, refining activities, and smelting as well as waste incinerations.

\section{Summary and Recommendation}

The geochemical assessment of heavy metals in the investigated three deltaic lakes sediments revealed that, $\mathrm{Zn}$ and $\mathrm{Pb}$ have low potential ecological risk factor, $\mathrm{Cu}$ in Lakes Edku and Burullus shows low potential ecological risk factor while in Lake Manzala it shows moderate potential risk factor. Cd in Lake Edku expressed high potential ecological risk factor, while in Lake Burullus and especially in Lake Manzala shows

Egypt. J. Chem. 60, No. 3 (2017) 
very high ecological risk factor.

The heavy metals of the present deltaic lakes sediments are also compared with the three pollution standard levels modified by FreretMeurer [44]. These levels are; the lowest effect level (LEL), the heavily polluted category (HPC) and the severe effect level (SEL). In Lake Manzala $\mathrm{Mn}, \mathrm{Cd}$ and $\mathrm{Cu}$ show values higher than SEL, Fe and Pb show values less than SEL but higher than HPC. In lake Burullus, Mn show higher values than $\mathrm{SEL}, \mathrm{Fe}, \mathrm{Cd}, \mathrm{Cu}$ and $\mathrm{Pb}$ show values less than SEL, but are higher than HPC, $\mathrm{Pb}$ is lower than LEL. In lake Idku, Mn shows values higher than SEL, Fe shows values higher than $\mathrm{HPC}$. While $\mathrm{Cd}, \mathrm{Cu}$ and $\mathrm{Pb}$ show values less than HPC and higher than LEL.

The environmental change in the northern deltaic lakes is very rapid and continuous so that the assessment and management of pollution risk must be also fast and decidable. It should be taken into consideration the importance of the continuous monitoring of the sediments, water as well as the biological organisms in these lakes with special attention to Lake Manzala.

Much effort and great attention should be done to make a proper treatment of domestic, agricultural and industrial effluents before releasing them into the coastal deltaic lakes.

The fishermen, activities and aquaculture industries must be managed and developed, it required improving the fishing vessels, applying more modern fishing technology, applying firming laws and rules for fishing activities.

The geographic investigation (GIS data), the geochemical information of the heavy metal pollutants, as well as the remote sensing data about the northern deltaic lakes must be collected periodically, coupled together, upgraded to be helpful for any environmental aspect threatening the ecosystem of the deltaic lakes or concerning any changes that take place on the delta coast, such as barrier erosion, land subsidence, inlet siltation and rising of the sea level.

\section{References}

1. EL-Bady, M. S. M New approach for the occurrence and characteristics of the coastal sand dunes, North of Nile Delta, Egypt. International Journal of

Egypt. J. Chem. 60, No. 3 (2017)
ChemTech Research, 9(7): 61-72, (2016).

2. EL-Bady, M.S.M. and Samy, Y. Economic heavy minerals in the coastal area between Burg ELBurullus and Baltim north of Nile Delta, Egypt. International Journal of ChemTech Research, 9(9): 110-117, (2016).

3. Bernasconi, M. P. and Stanley, D. J. Molluscan Biofacies and their environmental implication, Nile Delta Lagoons, Egypt. Journal of Coastal Research, 10: 440-465, (1994).

4. El Hawary, M. A. The zooplankton of the Egyptian Lakes. 1. A preliminary study on the zooplankton of Lake Maryut and Lake Idku. Hydrobiological Institute of Alexandria. Notes and Memoirs, 52, 16 (1960).

5. Saeed, M. S. and Shaker, I. M. Assessment of heavy metals pollution in water and sediments and their effect on Oreochromis niloticus in the northern Delta Lakes, Egypt. 8th International Symposium on Tilapia in Aquaculture, 475-490 (2008).

6. Chen, Z., Salem, A., Xu, Z .and Zhang, W. Ecological implications of heavy metal concentrations in the sediments of Burullus Lagoon of Nile Delta, Egypt. Estuarine, Coastal and Shelf Science, 86, 491-498, (2010).

7. Saad, M. A. H. State of the Egyptian delta lakes, with particular reference to pollution problems. Regional Symposium of Environmental studies (UNARC), Alexandria, Egypt, (1990).

8. Elewa, A. A., Saad, E. A., Shehata, M. B. and Ghallab, M. H. Studies on the effect of drain effluents on the water quality of Lake Manzala, Egypt. J. Aquat. Biol. \& Fish., 11(2), 65 - 78 (2007).

9. Mohamed, H. H. A. Assessment of some water quality characteristics and determination of some heavy metals in Lake Manzala, Egyptian Journal of Aquatic Biology and Fisheries, 12(2), 133 -154 (2008).

10. Bishai, H. N. and Yousef, S. F., Some aspects of the hydrography, physic-chemical characteristics and fisheries of Lake Manzala. UAR Bulletin of the Institute of Oceanography and Fisheries, 7, 1-30(1977).

11. Hamza, W. Estuary of the Nile. In: Wangersky, 
P. (Ed.), Estuaries; Handbook of Environmental Chemistry. Springer Verlage, Heidelberg, 5(H), 149173 (2006).

12. Siegel, F. R., Slaboda, M. L. and Stanley, D. J. Metal pollution loading, Manzala lagoon, Nile Delta, Egypt: Implications for aquaculture. Environmental Geology, 23, 89-98 (1994).

13. Soliman, A. A. M., Suliman, A. I. A. and Morsy, A. H. A. Productive performance of growing lambs fed on unconventional diets based on ground date palm seeds. Egyptian Journal of Animal Poultry Management, 1,101-119 (2006).

14. Abdel Moati, M. A. and A. A. El-Sammak. Manmade impact on the geochemistry of the Nile Delta Lakes. A study of metals concentrations in sediments. Water, Air and Soil Pollution, 97, 413-429 (1997).

15. Boyd, C. E. and Tucker, C. S. Emergency aeration of fish ponds. Transactions of the American Fisheries Society, 108, 299-306 (1979).

16. Duquesne, S., Newton, L. C., Giusti, L., Marriott, S. B., Stark, A. J. and Bird, D. J. Evidence for declining levels of heavy metals in the Severn Estuary and Bristol Channel, U.K., and their spatial distribution in sediments. Environmental Pollution, 143,187-196 (2006).

17. Farkas, A., Erratico, C. and Vigano, L. Assessment of the environmental significance of heavy metal pollution in surficial sediments of the River Po. Chemosphere, 68, 761-768 (2007).

18. Page, A. L., Miller, R. H. and Kenney, D. R. Heavy metals determination. In: Methods of Soil Analysis, Part 2, Chemical and Microbiological Properties. American Society of Agronomy, Madison, WI, USA. 8 pp, (1982).

19. El Ghobary, H. M. Sc. Thesis. Faculty of Science, Alexandria University, 136 p.(1977).

20. Moussa, A. A. Estimation of metal pollutant levels in sediments from Lake Borollus, Egypt. VI1, Journee Etud Pollutions, Lu cerne, C.L.E.S.M., 34-44 (1984).

21. Gu, J. W, Salem, A. and Chen, Z. Y. Lagoons of the Nile delta, Egypt, heavy metal sink: With a special reference to the Yangtze Estuary of China. Estuarine, Coastal and Shelf Science, 117, 282-292 (2013).
22. Abdallah, M. A., Gheith, A. M., El-Fayoumi, J. F. and Toubar, N. Mineralogical and geochemical significances of Burollus Lake sediments, North Nile Delta, Egypt. Egyptian Journal of Geology, 37(2), 323-346 (1993).

23. Samy, Y. M. and El-Bady, M. S. M. Comparative study of the mineralogy and geochemistry of the Burullus and Bardawil lake sediments, Mediterranean Sea Coast, Egypt. Life Science Journal, 11(9), 686-700 (2014).

24. Saad, M. A. H., Mcomas, S. R. and Eisenreich, S. J. Metals and chlorinated hydrocarbons in surficial sediments of three Nile delta lakes, Egypt. Water, Air and Soil Contamination, 24, 27-39 (1985).

25. Abdel Moati, A. R. and Dowidar, N. M. Trace elements of Lake Manzala Egypt. Bulletin of the National Institute of Oceanography and Fisheries A.R.E., 14, 183-202,(1988).

26. Abdel Baky, T. E., Hagras, A. E., Hassan, S. H. and Zyadah, M. A. Environmental impact assessment of pollution in Lake Manzala. 1-Distribution of some heavy metals in water and sediment. Journal of Egyptian German Society of Zoology, 26(B), 25-38 (1998).

27. Awfolu, O. R., Mbolekwa, Z., Mtshemla, V. and Fatoki, O. S. Levels of trace metals in water and sediment from Tyume River and its effects on an irrigated farmland, Water $S A$, 31(1), 87-94 (2005).

28. Abdel Satar, A. M. and Elewa, A. A. Water Quality and Environmental Assessments of the River Nile at Rosetta Branch. The Second International Conference and Exhibition for Life and Environment, 136-164 (2001).

29. Abdo, M. H. Distribution of some chemical elements in the recent sediments of Damietta branch, River Nile, Egypt. Journal of the Egyptian Academic Society of Environmental Development. (DEnvironmental Studies), 5(2), 125-146 (2004).

30. Berg, H., Kiibus, M. and Kautsky, N. Heavy metals in tropical Lake Kariba, Zimbabwe. Water, Air \& Soil Pollution, 83 (3/4), 237-252 (1995).

31. Sung, W. and Morgan, J. J. Oxidative removal of $\mathrm{Mn}$ (II) from solution catalysed by the $\gamma$-FeOOH (lepidocrocite) surface. Geochimica et Cosmochimica Acta, 45 (12), 2377-2383 (1981).

Egypt. J. Chem. 60, No. 3 (2017) 
32. Ali, M. H., Fishar, M. R. Accumulation of trace metals in some benthic invertebrate and fish species relevant to their concentration in water and sediment of lake Qarun, Egypt. Egyptian Journal of Aquatic. Research. 31(1), 289-301 (2005).

33. Hutchinson, G. E. A treatise on limnology. 1. Geography, Physics and Chemistry. John Wiley and Sons, New York, XIV, 1015 p. (1957).

34. Fedo, C. M., Eriksson ,K. and Krogstad, E. J. Geochemistry of shales from the Archean (3.0 Ga.) Buhwa Greenstone Belt. Zimbabwe; Implications for provenance and source area weathering. Geochimca et Cosmochimca Acta, 60, 1751-1763 (1996).

35. Franca, S., Vinagre, C., Cacador, I. and Cabral H.N. Heavy metal concentration in sediment, benthic invertebrates and fish in three salt marsh areas subjected to different pollution load in the Tagus Estuary (Portugal) baseline. Marine Pollution Bulletin, 50, 993-1018 (2005).

36. Biksham, G., Subramanian, V., Ramanathan, A. L. and Van Grieken, R. Heavy metal distribution in the Godavari River basin. Environmental Geology and Water Sciences. 17(2), 117-126 (1991).

37. Hankanson, L. An ecological risk index for aquatic pollution control. A sedimentilogical approach. Water Research, 14(8), 975-1001 (1980).

38. Tomilson, D. C., Wilson, D. J., Harris, C. R., Jeffrey, D. W. Problem in assessment of heavy metals in estuaries and the formation of pollution index. Helgol. Wiss Meeresunlter, 33 (1-4), 566-575 (1980).

39. Muller, G. Index of Geo-accumulation in sediments of the Rhine river. GeoJournal, 2, 108-118 (1969).

40. Praveena, S. M., Ahmed, A., Radojevic, M., Abdullah, M. H. and Ris, A. Z. Heavy metals in mangrove surface sediment of Mengkabong lagoon, Sabah: Multivariate and eoaccumulation index approaches. International Journal of Environmental Research, 2 (2), 139-148 (2008).

41. EL-Bady, M. S. M. Potential Ecological Risk Index of the Northern Egyptian Lagoons, South of Mediterranean Sea, Egypt. International Journal of ChemTech Research, 9(3), 172-190 (2016).

42. USPHS, Toxicological profile for zinc and lead on CD-ROM. Agency for Toxic Substances and Disease

Egypt. J. Chem. 60, No. 3 (2017)
Registry. U.S. Public Health Service, (1997).

43. Salomons, W. and Forstner, U. Metals In The Hydrocycle. Springer Verlag, Berlin Heidelberg, New York. 349 pp, (1984).

44. Freret-Meurer, N. V., Andreata, J. V., Meurer, B. C., Manzano, F. V., Baptista, M. G. S., Teixeira, D. E. and Longo, M. M. Spatial distribution of metals in sediments of the Riberia Bay, Angra dos Reis, Rio de Janeiro, Brazil. Marine Pollution, 60, 627-629 (2010).

45. Turekian, K. K., and Wedepohl, K. H. Distribution of the elements in some major units of the Earth's crust. Geological Society of America, Bulletin, 72(2), 175-192 (1961).

46. Fanos, A.M., Khafagy, A.A. and Dean, R.G. Protective works on the Nile Delta coast. Journal of Coastal Research, 11, 516-528, (1995).

47. Frihy, O. E. Sea-level rise and shoreline retreat of the Nile Delta promontories, Egypt. Natural Hazards, 5: 65-81, (1992).

48. EL-Bady, M. S. M. New approach for calculation of pollution indices of the soils by heavy metals: case study for soils of Bahr El-Baqar Region, South of Manzala Lagoon, Egypt. International Journal of ChemTech Research, 9(4), 461-474 (2016).

49. Frihy, O. E., Dewidar K., Nasr, S. and El Raey, M. M. Change detection of the northern Nile delta of Egypt: shoreline changes, Spit evolution, margin changes of Manzala lagoon and its islands. International Journal of Remote Sensing, 19, 1901-1912 (1998).

50. Guirguis, S. K., Hassan, H. M., El-Raey, M. E. and Hussain, M. M. A., Multi-temporal change of lake Burullus, Egypt, from 1983 to 1991. International Journal of Remote Sensing, 17(15), 2915 - 2921, (1996).

51. Stanely, D.J and Warne, A. G. Nile delta: recent geological evolution and human impact. Sceince, 260, 628-634 (1993).

52. Siegel, D. A., Maritorena, S. Nelson, N. B., Behrenfeld, M. J. and McClain, C. R. Colored dissolved organic matter and its influence on the satellite-based characterization of the ocean biosphere. Geophysical Research Letters, 32, L20605, doi:10.1029/2005GL024310 (2005). 
53. Okbah, M. A. and El-Gohary, S. Physical and Chemical Characteristics of Lake Edku Water, Egypt. Mediterranean Marine Science, 3(2), 27-39 (2002).

54. Abdel Moati, A. R. Behaviour and fluxes of copper and lead in the Nile River estuary. Estuarine, Coastal and Shelf Science, 30, 153-165 (1990).

55. Kamal, H. S. and Magdy, T. K. Socioeconomic features. In: Kamal, H.S., Magdy, T. K. (Eds.), Lake Burullus (Burullus Protected Area). Publication of National Biodiversity Unit, Cairo, 578p. (2005).

56. Samir, M. S. and Shaker, I. M. Assessement of heavy metals pollution in water and sediments and their effect on Oreochromis Niloticus in the northern delta lakes, Egypt. 8th International Symposium on Tilapia in Aquaculture, 475-490 (2008).

57. Abdel Azeem, A. M., Abdel-Moneim, T. S., Ibrahim, M. E., Hassan, M. A. A. and Saleh, M .Y. Effects of long-term heavy metal contamination on diversity of terricolous fungi and nematodes in Egypt. A case study. Water Air and Soil Contamination, 186, 233254, (2007).

58. Siegel, F. R., Gupta, N., Shergill, B., Stanley, D. J. and Gerber, C. Geochemistry of Holocene sediments from the Nile Delta. Journal of Coastal Research,

$$
\text { 11, 415-431 (1995). }
$$

59. Barakat, A. O. Assessment of persistent toxic substances in the environment of Egypt. Environment International, 30(3), 309-322 (2004).

60. Abdel Satar, A. M., Environmental studies on the impact of the drains effluent upon the southern sector of Lake Manzala, Egypt. Egyptian Journal of Aquatic Biology \& Fisheries, 5(3), 17- 30 (2001).

61. El Rayis, O. E. Impact of man's activities on a closed fishing-lake, Lake Mariut in Egypt, as a case study. Mitigation and Adaptation Strategies for Global Change, 10, 145-157 (2005).

62. Lavery, J.T., Kemper, M.C., Sanderson, K., Schultz, G. C., Coyle, P., Mitchell, G.J. and Seuront, L. Heavy metal toxicity of kidney and bone tissues in South Australian adult bottlenose dolphins (Tursiops aduncus). Marine Environmental Research, 67: 1-7, (2009).

63. Khalifa, M. M. and Kandrashim, R. V. Detect risk zone of heavy metals contamination in water of the Lake Mariut, Alexandria, Egypt. Ecmecmeehhb/e Hayku., 43(2), 72-81,(2013).

Received 16/4/2017, accepted $21 / 5 / 2017$

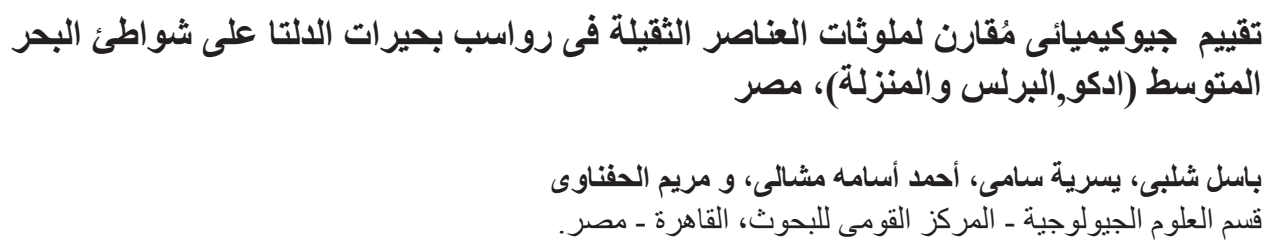

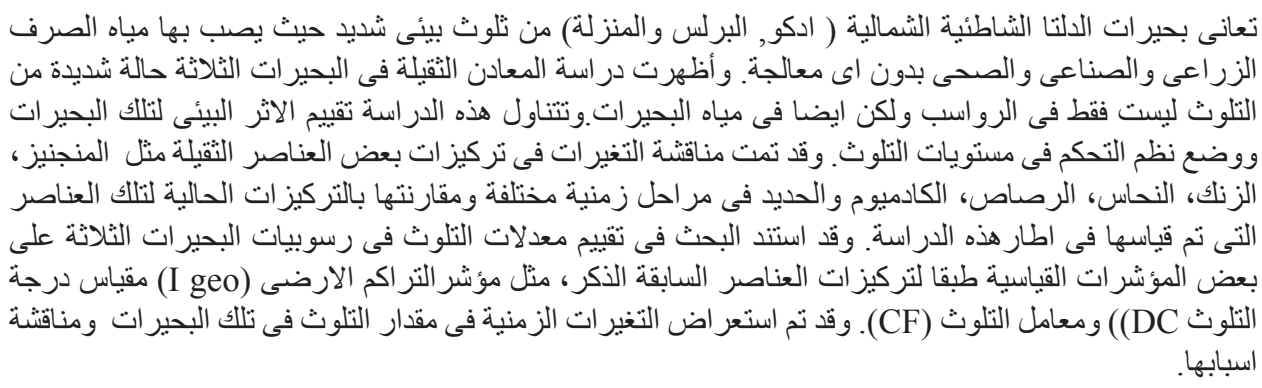

Egypt. J. Chem. 60, No. 3 (2017) 